Jurnal Penyuluhan, Maret 2013 Vol. 9 No. 1

\title{
Persepsi Pemuda Pencari Kerja Terhadap Pekerjaan Sektor Pertanian dan Pilihan Pekerjaan di Desa Cihideung Udik Kecamatan Ciampea, Kabupaten Bogor
}

\section{Perception on Agriculture Jobs and Job Preference Among Youth Unemployed in Cihideung Udik, Ciampea District, Bogor Regency}

\author{
Meziriati Hendri ${ }^{1}$, Ekawati Sri Wahyuni ${ }^{1}$ \\ ${ }^{1}$ Departemen Sains Komunikasi dan Pengembangan Masyarakat, \\ Fakultas Ekologi Manusia, Institut Pertanian Bogor
}

\begin{abstract}
This research aim to analyse the perception on agricultural employment and to analyse job preferences among rural youth unemployed in Cihideung Udik village. This research was conducted using quantitative research approach enhanced with qualitative data. The number of respondents were 40 youth job seekers The research result shows that job seekers internal factors, such as, women have some skills and some job experience as well as external factors such as, low socio economic level, less cosmopolitant, and agricultural employment experiences tend to have negative perceptions on agricultural employment. Rural youth unemployed in this village prefer to work in non agricultural sectors, such as in manufacturing sector in area around Bogor and Jakarta.
\end{abstract}

Keyword: perception, unemployment, rural youth, agricultural employment, non agricultural employment

\section{Abstrak}

Penelitian ini bertujuan untuk menganalisis persepsi terhadap kesempatan kerja pertanian dan untuk menganalisis preferensi pekerjaan di kalangan pemuda pengangguran di Desa Cihideung Udik. Penelitian ini dilakukan dengan menggunakan pendekatan penelitian kuantitatif ditingkatkan dengan data kualitatif. Jumlah responden adalah 40 pencari kerja muda Hasil penelitian menunjukkan bahwa pencari kerja faktor internal seperti, wanita memiliki beberapa keterampilan dan pengalaman kerja serta faktor eksternal seperti, tingkat rendah sosial ekonomi, kurang kosmopolit dan pengalaman kerja pertanian cenderung memiliki persepsi negatif terhadap lapangan kerja pertanian. Pemuda pedesaan pengangguran di desa ini lebih memilih untuk bekerja di sektor pertanian non, seperti di sektor manufaktur di daerah sekitar Bogor dan Jakarta.

Kata Kunci: persepsi, pengangguran, pemuda pedesaan, pekerjaan pertanian, lapangan kerja non pertanian

\section{Pendahuluan}

Pengangguran adalah seseorang individu yang termasuk kelompok penduduk usia kerja yang selama periode tertentu tidak bekerja, dan bersedia menerima pekerjaan, serta sedang mencari pekerjaan (BPS, 2013). Depnakertrans (2012) menyatakan bahwa jumlah pengangguran terbuka atau penduduk yang sedang mencari kerja di Indonesia tergolong tinggi yaitu sebanyak 7.244.956 jiwa dan 40\% diantaranya merupakan lulusan Sekolah Menengah Atas atau sederajat. Pendidikan masyarakat di Indonesia saat ini mengalami peningkatan setiap tahunnya. Hal ini terlihat dengan peningkatan angka partisipasi pendidikan masyarakat Indonesia yang tidak hanya di daerah perkotaan, akan tetapi juga sudah mulai merata sampai ke daerah pedesaan. Tentunya hal ini menjadi suatu nilai tambah yang bagus dengan meningkatnya kualitas sumber daya manusia di ${ }^{1}$ Korespondensi penulis

E-mail: Hendri.Meziriati@gmail.com negeri ini. Simanjuntak (1985) berpendapat bahwa pendidikan tidak hanya meningkatkan pengetahuan, tetapi juga keterampilan dan produktivitas kerja yang nantinya akan meningkatkan penghasilan yang didapatkan.

Terutama untuk daerah di pedesaan yang sebagian besar masih berada oleh sektor primer. Hal ini seharusnya akan semakin meningkatkan produktifitas dan hasil dari berbagai sektor primer yang ada di desa, salah satunya seperti bidang pertanian. Akan tetapi hal yang ditemukan saat ini yaitu semakin tinggi pendidikan seseorang semakinmenurunkanminatnya ke arah pertanian. Fenomena ini semakin diperkuat oleh data penduduk yang bekerja di sektor pertanian pada tahun 2008 - 2012. Data Depnakertrans (2012) menunjukkan bahwa telah terjadi penurunan jumlah masyarakat yang bekerja di sektor pertanian dari 41\% pada tahun 2008 hingga hanya $35 \%$ pada tahun 2012 dari total seluruh penduduk yang bekerja. 
Lebih lanjut, Prihatmoko (2013) menyatakan bahwa berdasarkan data BPS jumlah tenaga kerja di sektor pertanian merosot tajam dari 42,28 juta orang pada Februari 2011 hingga sebanyak 39,96 juta orang pada Februari 2013. Hal ini mengindikasikan bahwa tenaga kerja di Indonesia mulai banyak beralih ke sektor di luar pertanian.

Penelitian Raharjo (2004) mengemukakan hasil penelitian di Missouri (AS) yang mendapatkan kenyataan bahwa pemuda yang mempunyai tingkat pendidikan atau kecakapan yang terbaik telah meninggalkan daerah sektor pertanian dan beranjak ke daerah non pertanian seperti kota. Dalam kata lain, pemuda desa saat ini terutama yang telah berpendidikan minimal SMA sederajat cenderung untuk tidak berminat lagi dan memiliki persepsi kurang baik terhadap pekerjaan pertanian walaupun masih berada di lingkungan daerah pertanian. Dewasa ini telah terdapat beberapa penelitian yang melihat pandangan atau persepsi pemuda terhadap pekerjaan di sektor pertanian, seperti penelitian yang dilakukan oleh Herlina (2002) yang meneliti tentang orientasi nilai kerja pemuda pada keluarga petani perkebunan, penelitian yang dilakukan oleh Anshori (2011) mengenai persepsi dan minat pemuda terhadap pekerjaan pertanian, kemudian penelitian Chandra (2004) yang meneliti mengenai persepsi pemuda desa terhadap pekerjaan di pertanian dan minat bekerja di kota. Berdasarkan penelitian yang dilakukannya, Chandra (2004) merekomendasikan untuk mengadakan penelitian lebih lanjut tentang persepsi pemuda desa yang sudah tidak bekerja di sektor pertanian terhadap pekerjaan pertanian untuk memperkuat hasil penelitiannya.

Rakhmat (2003) mengatakan bahwa persepsi seseorang mengenai suatu hal akan mempengaruhi perilaku seseorang terhadap hal tersebut. Pemuda desa yang sedang mencari pekerjaan saat ini banyak yang sudah berpendidikan hingga SMA sederajat dan mereka telah meninggalkan pekerjaan pertanian, terlihat dengan usaha mereka untuk melamar di berbagai sektor pekerjaan lain dan mengalami beberapa kali pergantian pekerjaan di luar sektor pertanian. Pemuda yang melakukan hal ini masih berada pada wilayah dengan sektor pertanian yang menjadi mayoritas pekerjaan penduduk. Hal ini seperti yang ditemukan pada pemuda di Desa Cihideung Udik, Kecamatan Ciampea, Kabupaten Bogor. Melihat fenomena tersebut menimbulkan pertanyaan sebenarnya bagaimanakah persepsi pemuda pencari kerja yang berpendidikan terhadap sektor pertanian saat ini?

Penelitian ini diharapkan dapat bermanfaat bagi berbagai kalangan. Bagi akademisi penelitian ini diharapkan dapat menjadi bahan referensi dan kajian untuk penelitian selanjutnya mengenai kondisi tenaga kerja muda di desa secara umunya dan pilihan pekerjaan pemuda desa saat ini secara khususunya. Selain itu, bagi pemerintah diharapkan dapat menjadi bahan pertimbangan dan meningkatkan perhatian terhadap kondisi pemuda dan ketenagakerjaan pertanian di desa. Kemudian bagi masyarakat diharapkan dapat menjadi tambahan informasi mengenai fakta tentang kondisi tenaga kerja muda di bidang pertanian saat ini.

\section{Metode Penelitian}

Metode yang digunakan dalam penelitian ini adalah metode kualitatif yang didukung oleh data kualitatif. Hal ini dilakukan untuk memperkaya data dan lebih memahami fenomena sosial yang diteliti (Singarimbun, 1989). Teknik penelitian yang digunakan dalam penelitian kuantitatif adalah teknik penelitian survei. Penelitian survei adalah penelitian yang datanya dikumpulkan dari sampel atas populasi untuk mewakili seluruh populasi. Informasi yang dikumpulkan dalam penelitian survei adalah informasi dari responden dengan menggunakan kuesioner. Unit analisa yang digunakan pada penelitian ini adalah individu.

Penelitian dilakukan di Desa Cihideung Udik, Kecamatan Ciampea, Kabupaten Bogor. Pemilihan lokasi dalam penelitian ini dilakukan secara sengaja (purposive) berdasarkan pertimbangan bahwa daerah tersebut merupakan daerah pertanian dan banyaknya jumlah pemuda di desa ini yang berpendidikan sampai SMA sederajat yang sedang mencari pekerjaan di luar sektor pertanian. Penelitian dilakukan dari Oktober 2013 hingga Desember 2013 yang dimulai dari proses observasi awal, pendekatan dengan masyarakat setempat, penentuan responden, pengumpulan data, pengolahan data dan berakhir dengan penulisan hasil penelitian

Penelitian ini menggunakan pendekatan penelitian kuantitaif yang didukung data kualitatif. Alat ukur yang digunakan untuk mengumpulkan data kuantitatif adalah kuesioner dan pengumpulan 
data kualitatif dilakukan melalui observasi dan wawancara mendalam. Populasi dalam penelitian ini adalah seluruh pemuda pencari kerja lulusan SMA yang ada di desa Cihideung Udik, Kabupaten Bogor. Kerangka sampling dari penelitian ini adalah pemuda Desa Cihideung Udik yang sedang mencari pekerjaan dan merupakan lulusan SMA sederajat dalam empat tahun terakhir. Berdasarkan hasil observasi di lapangan, maka didapatlah 68 orang pemuda yang menjadi kerangka sampling.

Responden didefinisikan sebagai bagian dari kerangka sampling yang sebelumnya telah ditentukan. Jumlah responden dalam penelitian ini adalah 40 orang. Teknik penentuan responden dilakukan melalui teknik simple random sampling, yaitu dengan mengundi secara acak seluruh kerangka sampling hingga didapatlah 40 responden. Selain responden, terdapat juga informan untuk melengkapi data secara kualitatif. Informan yang dipilih adalah pihak-pihak yang memiliki informasi yang diperlukan seperti informasi pertanian yang akan ditanyakan langsung kepada petani yang ada di desa tersebut, dan informasi mengenai profil desa dan dinamika kehidupan sosial budaya masyarakat setempat yang akan ditanyakan kepada kepala desa, tokoh masyarakat, dan pihak lainnya yang dianggap memiliki informasi terhadap kasus yang diteliti Teknik Pengolahan dan Analisis Data

Data primer didapatkan melalui wawancara mendalam dengan menggunakan kuesioner kepada responden. Data tersebut akan di edit terlebih dahulu. Proses editing dilakukan untuk membaca dan memberi koreksi pada setiap kuesioner yang telah diisi. Proses editing ini berguna untuk mengecek kelengkapan data dan logika urutan jawaban atas setiap pertanyaan dalam kuesioner. Setelah itu dilakukan pengkodean data dengan cara membuat buku kode pada Microsoft exce/2010, hal ini dilakukan dengan penyusunan secara sistematis data mentah (yang terdapat dalam kuesioner) kedalam bentuk yang mudah dibaca oleh komputer. Selanjutnya data tersebut dipindahkan ke software SPSS 16.0 untuk dianalisis lebih lanjut. Analisis data menggunakan beberapa alat analisis deskriptif berupa tabel frekuensi, tabulasi silang, gambar, dan grafik untuk melihat pengaruh faktor internal dan eksternal terhadap persepsi terhadap pekerjaan pertanian. Selain itu, untuk melihat hubungan antar variabel digunakan uji statistik non-parametrik melalui uji Chi-Square dan Spearman. Kedua variabel dikatakan berhubungan apabila nilai hasil uji (nilai p) lebih kecil dari pada nilai $\alpha$ (alfa). Nilai alfa $(\alpha)$ yang digunakan di sini yaitu 10 persen $(0,1)$. Secara lebih rinci untuk melihat keterhubungan antar variabel dijelaskan sebagai berikut.

\section{Hipotesa:}

H0 : kedua variabel tidak berhubungan, H1 : kedua variabel berhubungan.

Kriteria uji : Tolak H0 jika nilai $\mathrm{p}<\alpha$, terima H0 jika nilai $\mathrm{p}>\alpha$.

Ketika hasil nilai $\mathrm{p}$ lebih kecil dari alfa $(\alpha)$ maka tolak $\mathrm{H} 0$ artinya terima $\mathrm{H} 1$ yang berarti kedua variabel memiliki hubungan. Begitupun sebaliknya, ketika nilai plebih besar dari alfa $(\alpha)$, maka H0 diterima yang artinya kedua variabel tidak berhubungan.

Data pada kuesioner tersebut dikelompokkan dan diberi nilai sesuai dengan definisi operasional. Definisi operasional dari setiap variabel disusun berdasarkan teori dan mengacu kepada jawaban responden pada kuesioner. Definisi operasional yang mengacu pada jawaban responden yaitu seperti pendapatan serta perangkingan pada tingkat kosmopolitan dan status sosial ekonomi. Variabel tingkat pendapatan didapatkan dari rata-rata pendapatan seluruh responden. Pada kuesioner, kolom pendapatan diisi dengan pendapatan orangtua responden berdasarkan satuan waktu menerima pendapatan masing-masing, yaitu perhari, perminggu dan perbulan. Kemudian seluruhnya di konversikan menjadi satu satuan waktu yang sama yaitu menjadi pendapatan dalam waktu satu bulan untuk mempermudah membuat perbandingan. Setelah itu, barulah ditemukan rata-rata pendapatan perbulan, yaitu Rp 2.045.000,-.

Untuk perangkingan pada variabel status sosial ekonomi, dilihat berdasarkan luas lahan yang dimiliki, pekerjaan, pendapatan dan pendidikan orang tua responden. Berdasarkan keempat hal tersebut, didapatlah skor total dan rata-rata. Skor yang berada di bawah atau sama dengan rata-rata dikategorikan sebagai rendah dan skor total yang berada di atas rata-rata dikategorikan sebagai tinggi. Selain analisis data kuantitatif, dilakukan pula analisis data secara kualitatif sebagai pendukung dengan mengutip hasil wawancara mendalam dengan responden atau informan guna mempertajam hasil penelitian. 


\section{Hasil dan Pembahasan}

\section{Karakteristik pribadi}

Responden dalam penelitian ini merupakan pemuda pencari kerja yang merupakan lulusan Sekolah Menengah Atas atau sederajat dalam 4 tahun terakhir. Hal ini menyebabkan umur responden tidak jauh berbeda, hanya berkisar antara 18 tahun hingga 21 tahun. Untuk pendidikan, pemuda di Desa Cihideung Udik lebih banyak lulusan Sekolah Menengah Kejuruan (SMK) yang mencapai 75\% dari total responden. Banyaknya mereka yang lebih memilih untuk mengambil SMK ini disebabkan oleh orientasi mereka untuk langsung bekerja setelah lulus SMK nanti. Pada umumnya mereka tidak mau lagi melanjutkan ke jenjang yang lebih tinggi seperti akademi ataupun universitas. Hal ni seperti yang diungkapkan Ahd (18) ketika ditanya mengapa lebih memilih masuk SMK,

\section{"Saya sih pengen langsung dapat kerja Teh, gak mau kuliah lagi, kalau masuk SMA kan gak ada keahlian, susah buat nyari kerja, jadi harus kuliah dulu' (Ahd, 18 tahun).}

\section{Riwayat Pekerjaan}

Pemuda yang memiliki pekerjaan atau kegiatan produktif secara ekonomi hanya 35\%. Pekerjaan yang mereka lakukan tersebut seperti menjadi tukang ojek, ikut dalam pekerjaan bengkel, dan ikut bekerja di bangunan. Walaupun demikian kegiatan tersebut tidak dilakukannya secara terus-menerus, hanya ketika ada yang mengajak saja. (Tabel 1).

Pemuda Desa Cihideung Udik ini sebagian besar tidak memiliki kegiatan apapun $(65 \%)$. Mereka hanya menunggu lamaran yang mereka ajukan diterima dengan menghabiskan waktu menonton televisi di rumah dan bermain bersama teman-

Tabel 1 Jumlah dan Persentase Pemuda Berdasarkan Kegiatan

\begin{tabular}{lcc}
\hline \multicolumn{1}{c}{ Kegiatan } & Jumlah & $\begin{array}{c}\text { Persentase } \\
\text { (\%) }\end{array}$ \\
\hline Bekerja & 14 & 35 \\
Tidak bekerja & 26 & 65 \\
\hline Jumlah & 40 & 100 \\
\hline
\end{tabular}

Tabel 2 Jumlah dan Persentase Responden Berdasarkan Lamaran yang Pernah Lolos

\begin{tabular}{lcc}
\hline $\begin{array}{c}\text { Lamaran yang } \\
\text { pernah lolos }\end{array}$ & Jumlah & $\begin{array}{c}\text { Persentase } \\
(\mathbf{\%})\end{array}$ \\
\hline Ya & 22 & 55 \\
Tidak & 18 & 45 \\
\hline Jumlah & 40 & 100 \\
\hline
\end{tabular}

teman sebaya setiap harinya. Tidak ada kegiatan yang produktif secara ekonomi yang dilakukan selama menunggu lamaran yang diajukan diterima, terutama untuk perempuan. Mereka hanya di rumah dan membantu pekerjaan rumah tangga. Dari seluruh responden terdapat 22 orang atau 55\% responden yang lamarannya pernah lolos sampai tahap tertentu saja, sedangkan 45\% lainnya menyatakan lamaran pekerjaan yang diajukan tidak pernah lolos tahap manapun (Tabel 2).

Sebagian pemuda yang lamarannya lolos pernah tidak mengambil pekerjaan yang telah ia usahakan tersebut dengan alasan terkait izin dari orang tua karena pekerjaan dinilai terlalu jauh, selain itu terdapat alasan ketidakcocokan upah dan alasan kesehatan. Ketidakcocokan upah di sini yaitu ketika lamaran pekerjaan dinyatakan diterima dan kemudian diketahui upah yang akan didapatkan dari pekerjaan tidak sesuai dengan yang diharapkan, mereka akan langsung mundur dan membatalkan bekerja di tempat tersebut.

\section{"Saya gak jadi ambil karena cuma digaji Rp 800.000, - sebulan teh, kecil amat, mending saya cari yang lain dulu' ( RH, 20 tahun).}

Sebagian dari responden telah memiliki pengalaman bekerja sebelumnya. Alasan utama mereka meninggalkan pekerjaan yang telah pernah ia dapatkan tersebut yaitu ketidakcocokan upah dan waktu kerja. Upah yang didapatkan pada pekerjaan yang sebelumnya sangatlah minim dan jauh dari

Tabel 3 Jumlah dan Persentase Persepsi Pemuda Desa Cihideung Udik terhadap Pekerjaan Pertanian

\begin{tabular}{clcc}
\hline No & Persepsi & Jumlah responden & $\begin{array}{c}\text { Persentase } \\
\mathbf{( \% )}\end{array}$ \\
\hline 1 & Positif & 7 & 17,5 \\
2 & Negatif & 33 & 82,5 \\
\hline \multicolumn{2}{l}{ Total } & 40 & 100,0 \\
\hline
\end{tabular}


Tabel 4 Jumlah dan Persentase Responden berdasarkan Jenis Kelamin

\begin{tabular}{clrc}
\hline No & Jenis Kelamin & Jumlah & Persentase (\%) \\
\hline 1 & Laki-laki & 33 & 82,5 \\
2 & Perempuan & 7 & 17,5 \\
\hline Total & & 40 & 100,0
\end{tabular}

Upah Minimum Regional (UMR) setempat. Selain itu, ada juga upah yang dirasa sudah mencukupi kehidupannya tapi jam kerja yang terlalu panjang membuat responden memutuskan untuk keluar dari pekerjaan tersebut. Selain itu juga disebabkan faktor jarak atau jauhnya tempat bekerja dari tempat responden berdomisili. Hal ini terutama terjadi pada perempuan. Orangtua pada umumnya sangat mempermasalahkan jarak tempat responden bekerja, jika jarak tersebut dirasa terlalu jauh, akan langsung disuruh berhenti dan diminta untuk bekerja yang dekat dengan tempat tinggal mereka saja.

Sebagian besar responden yang memiliki pengalaman bekerja sebelumnya memiliki pendapatan kurang dari Rp 1.000.000,- perbulan. Rata-rata mereka hanya digaji $R p$ 600.000,- hingga $R p$ 850.000,perbulan, bahkan ada yang kurang dari Rp 500.000,perbulan. Mereka merasa hal ini tidak sesuai dengan ijazah yang dimilikinya. Salah seorang responden, mengemukakan hal tersebut ketika bercerita tentang pengalaman bekerjanya.

"Saya sih cuma digaji Rp.600.000,- per bulannya teh, padahal saya harus kerja dari jam 8 pagi sampai jam 6 sore, saya merasa sama saja dengan orang yang lulus SD, padahal 'jazah saya SMA' (Ads, 21 tahun).

\section{Persepsi terhadap Pekerjaan Pertanian}

Pemuda Desa Cihideung Udik sebagian besar mengatakan bahwa bekerja di pertanian itu lebih melelahkan karena ketika bekerja di sektor pertanian Tabel 5 Jumlah dan Persentase Responden yang Memiliki Keterampilan

\begin{tabular}{lcc}
\hline \multicolumn{1}{c}{ Keterampilan } & Jumlah & Persentase \\
\hline $\begin{array}{l}\text { Tidak memiliki } \\
\text { keterampilan }\end{array}$ & 26 & 65 \\
$\begin{array}{l}\text { Memiliki } \\
\text { keterampilan }\end{array}$ & 14 & 35 \\
\hline Jumlah & 40 & 100 \\
\hline
\end{tabular}

Tabel 6 Jumlah dan Persentase Pengalaman Bekerja yang Dimiliki Responden

\begin{tabular}{lcc}
\hline Jumlah pengalaman bekerja & Jumlah & $\begin{array}{c}\text { Persentase } \\
(\mathbf{\%})\end{array}$ \\
\hline Memiliki pengalaman bekerja & 22 & 55 \\
Tidak punya pengalaman bekerja & 18 & 45 \\
\hline Jumlah & 40 & 100 \\
\hline
\end{tabular}

mereka harus bekerja di luar ruangan dengan berbagai kondisi cuaca, baik itu panas maupun hujan. Apalagi ketika panas, mereka harus tetap bekerja dengan pekerjaan yang membutuhkan tenaga yang besar karena harus mencangkul dan bersusah payah di sawah atau ladang dengan pekerjaan yang kasar. Inipun juga mereka dapatkan ketika mereka harus bekerja di pabrik atau di tempat lain, hanya saja ketika bekerja di pabrik tidak tersentuh kondisi cuaca. Hal inilah yang membuat penilaian mengapa bekerja di pertanian itu lebih melelahkan daripada bekerja di tempat lain. Akan tetapi, masih ada pemuda yang menilai bekerja di pertanian itu lebih santai. Penilaian seperti ini mereka berikan dengan alasan bekerja di pertanian tersebut tidak harus pergi pagi serta pulang malam seperti bekerja di pabrik atau bekerja di tempat lain.

Lain lagi dengan penilaian mereka mengenai pendapatan yang dihasilkan dari pekerjaan di sektor pertanian. Sebagian besar responden menilai pekerjaan pertanian itu menghasilkan pendapatan yang lebih besar jika dibandingkan dengan bekerja di tempat yang lain. Apalagi jika bekerja di pabrik, industri, atau bekerja di toko waralaba yang menghasilkan pendapatan sangat kecil. Berdasarkan pengalaman responden yang bekerja di pabrik, mereka hanya mendapatkan gaji Rp 1.200.000,sampai dengan Rp 1.800.000,- per bulan. Berbeda dengan bertani yang bisa menghasilkan lebih besar dari itu, walaupun demikian mereka tetap lebih memilih bekerja di luar pertanian karena kepastian pendapatan yang didapat setiap bulan. Begitupun dilihat dari penilaian pemuda terhadap orang yang cocok bekerja di sektor pertanian dilihat dari segi pendidikan. Sebagian besar mengatakan bahwa orang yang cocok untuk bertani adalah mereka yang tidak sekolah atau maksimal hanya sampai lulus SD saja. Pendidikan merupakan suatu tolak ukur yang penting bagi responden untuk menilai pekerjaan di sektor pertanian ini. Mereka mempertimbangkan usaha dan waktu yang telah dihabiskan bertahun- 
Jurnal Penyuluhan, Maret 2013 Vol. 9 No. 1

Tabel 7 Jumlah dan Persentase Persepsi Pekerjaan Pertanian berdasarkan Faktor Internal Responden

\begin{tabular}{|c|c|c|c|c|c|c|c|}
\hline \multirow{3}{*}{$\begin{array}{l}\text { Faktor } \\
\text { internal }\end{array}$} & \multicolumn{5}{|c|}{ Persepsi pekerjaan pertanian } & \multirow{3}{*}{ Jumlah } & \multirow{3}{*}{ Persentase $(\%)$} \\
\hline & \multirow[t]{2}{*}{ Negatif } & \multicolumn{3}{|c|}{ Positif } & \multirow[b]{2}{*}{$\%$} & & \\
\hline & & $\mathbf{n}$ & $\%$ & $\mathbf{n}$ & & & \\
\hline \multirow{2}{*}{ Jenis kelamin } & Laki-laki & 26 & 78,8 & 7 & 100,0 & 33 & 82,5 \\
\hline & Perempuan & 7 & 21,2 & 0 & 0,0 & 7 & 17,5 \\
\hline Jumlah & & 33 & 100,0 & 7 & 100,0 & 40 & 100,0 \\
\hline \multirow{2}{*}{ Keterampilan } & Tidak punya & 21 & 63,6 & 5 & 71,4 & 26 & 65,0 \\
\hline & punya & 12 & 36,4 & 2 & 28,6 & 14 & 35,0 \\
\hline Jumlah & & 33 & 100,0 & 7 & 100,0 & 40 & 100,0 \\
\hline \multirow{2}{*}{$\begin{array}{l}\text { Pengalaman } \\
\text { bekerja }\end{array}$} & Tidak punya & 15 & 45,0 & 3 & 43,0 & 18 & 45,0 \\
\hline & punya & 18 & 55,0 & 4 & 57,0 & 22 & 55,0 \\
\hline Jumlah & & 33 & 100,0 & 7 & 100,0 & 40 & 100,0 \\
\hline
\end{tabular}

tahun hanya untuk sekolah sehingga ketika mereka merasa sia-sia sudah mencapai hingga ke sekolah menengah atas atau merampungkan pendidikan hingga 12 tahun kalau hanya untuk bertani kembali. Pemuda desa Cihideung Udik cenderung memiliki persepsi yang rendah atau negatif terhadap pekerjaan sektor pertanian. Banyak dari responden menilai bekerja di pertanian tersebut merupakan hal yang sulit dijalani, menguras banyak tenaga, menghabiskan banyak waktu serta pendapatan yang tidak jelas. Pendapatan yang belum dapat dipastikan setiap kali panennya menjadi alasan mereka karena melihat keadaan cuaca dan lingkungan membuat pemuda menilai rendah pekerjaan di sektor pertanian. Selain semua hal yang disebutkan di atas, pendidikan menjadi salah satu faktor penting bagi responden dalammelihat suatu jenis pekerjaan. Ketika seseorang telah menyelesaikan pendidikannya hingga tingkat SMA, mereka dinilai sudah memiliki kapabilitas untuk mendapatkan pekerjaan yang layak di suatu perusahaan atau industri, bukan untuk di sawah. Hal ini menjadi suatu sumbangan besar dalam membuat penilaian terhadap bagaimana pekerjaan di sektor pertanian di mata mereka. Adapun untuk tingkat persepsi pemuda Desa Cihideung Udik terhadap pekerjaan di sektor pertanian dapat dilihat lebih rinci pada Tabel 3 .

Secara keseluruhan pemuda Desa Cihideung Udik memiliki persepsi yang negatif terhadap pekerjaan di sektor pertanian. Hal ini sepertinya tidak sejalan dengan hasil penelitian Chandra (2004) yang menemukan bahwa persepsi pemuda desa terhadap pekerjaan di sektor pertanian secara keseluruhan masih tinggi (positif). Latar belakang responden yang sebagian besar tidak berasal dari keluarga petani dan tidak memiliki lahan pertanian menjadi penyebab perbedaan hasil tersebut. Selain itu, tampaknya faktor pendidikan yang dimiliki responden juga berperan dalam membentuk penilaian pemuda desa terhadap pekerjaan pertanian ini. Herlina (2002) mengemukakan hal yang sama dalam penelitiannya, ia menemukan bahwa pemuda yang berpendidikan rendah atau hanya lulus SD memiliki persepsi terhadap pekerjaan sektor pertanian lebih baik dari pada pemuda dengan tingkat pendidikan yang lebih tinggi. Hal ini seperti yang diungkapkan Tobing (1994) dalam Setiawan (2007) bahwa semakin terdidik seseorang, harapan untuk mendapatkan pekerjaan yang diinginkan juga semakin tinggi.

\section{Faktor yang Mempengaruhi Persepsi Terhadap Pekerjaan Pertanian}

\section{Faktor internal}

Faktor internal yaitu kondisi atau keadaan spesifik individu yang berkaitan langsung dengan dirinya seperti jenis kelamin, pengalaman bekerja dan keterampilan.

\section{Jenis kelamin}

Responden pada penelitian ini mayoritas lakilaki yaitu $82,5 \%$ dari total seluruh responden. Hal ini disebabkan oleh selain masih sedikitnya pendidikan perempuan yang mencapai tingkat SMA sederajat, 
Tabel 8 Jumlah dan Persentase Responden berdasarkan Total Pendapatan Orangtua Perbulan

\begin{tabular}{lccc}
\hline No & $\begin{array}{c}\text { Total pendapatan } \\
\text { per bulan }\end{array}$ & Jumlah & $\begin{array}{c}\text { Persentase } \\
(\%)\end{array}$ \\
\hline $1 \quad \leq$ Rp.2.045.000,- & 25 & 63 \\
2 & $>$ Rp.2.045.000,- & 15 & 38 \\
\hline Total & 40 & 100 \\
\hline
\end{tabular}

juga dipengaruhi oleh lebih mudahnya perempuan yang berpendidikan SMA sederajat mendapatkan pekerjaan di daerah tersebut.

Dalammencaripekerjaan, rata-rata perempuan di daerah ini cenderung untuk mencari pekerjaan yang dekat dengan daerah mereka seperti tetap di daerah Bogor. Akan tetapi, lapangan pekerjaan pun memang banyak yang menawarkan untuk perempuan di daerah Bogor dalam beberapa waktu terakhir ini, seperti pabrik garmen yang terdapat di daerah Dramaga, dan banyaknya pembukaan lowongan SPG (Sales Promotion Gir).

\section{"Bulan lalu banyak sekali lowongan untuk SPG teh, hanya saja saya telat memasukkan lamaran, dan katanya bulan depan ada lagt' (Sr, 18 tahun).}

\section{Keterampilan}

Keterampilan di sini yaitu meliputi keahlian khusus yang dimiliki responden di luar pendidikan yang ditempuhnya dalam jalur formal. Pemuda Desa Cihideung Udik yang memiliki keterampilan hanya sebesar 35\%. (Tabel 5).

Keterampilan yang dimiliki responden berkisar pada perbengkelan, bangunan dan komputer. Selain itu juga terdapat servis hp, sablon, serta bengkel. Pada umumnya responden yang memiliki keterampilan mendapatkan keterampilan dari orang lain yang ada di sekitar mereka, seperti tentangga. Ini terjadi sekitar 38\% dari seluruh total responden, kemudian hal ini baru diikuti oleh kursus, diajarkan orang tua dan belajar sendiri. Keterampilan yang mereka dapatkan tersebut diharapkan dapat membantu mereka untuk mendapatkan pekerjaan yang lebih baik nantinya.

\section{Pengalaman bekerja}

Pengalaman bekerja di sini yaitu pengalaman
Tabel 9 Jumlah dan Persentase Pemuda berdasarkan Status Sosial Ekonomi Keluarga

\begin{tabular}{llcc}
\hline No & $\begin{array}{c}\text { Status sosial } \\
\text { ekonomi }\end{array}$ & Jumlah & $\begin{array}{c}\text { Persentase } \\
(\%)\end{array}$ \\
\hline 1 & Rendah & 25 & 62,5 \\
2 & Tinggi & 15 & 37,5 \\
\hline \multicolumn{2}{l}{ Total } & 40 & 100,0 \\
\hline
\end{tabular}

bekerja di luar sektor pertanian, yang dapat dilihat berdasarkan dua bagian, yaitu memiliki pengalaman bekerja dan belum pernah memiliki pengalaman bekerja (Tabel 6).

Sebagian besar responden telah pernah memiliki pengalaman bekerja sebelumnya. Kebanyakan dari mereka bekerja pada sektor industri/pabrik (34\%). Sektor ini menjadi sasaran utama yang diminati pemuda untuk melabuhkan pekerjaannya karena kemudahan dalam memasuki sektor tersebut dan banyaknya pembukaan lapangan pekerjaan pada bidang ini. Selain itu, bekerja di industri/pabrik memiliki nilai tersendiri bagi masyarakat di Desa Cihideung Udik, seperti pernyataan salah satu orangtua responden.

\section{"Kayak anak tetangga tuh neng, dia mah udah enak dapat kerja di pabrik, sudah aman lah' (St, 34 tahun)}

Masyarakat menilai bekerja di industri/ pabrik sudah memberikan suatu hal yang lebih baik untuk kehidupan di masa mendatang. Bekerja di pabrik dinilai menjadi suatu pekerjaan yang sudah layak untuk mereka yang telah mencapai pendidikan hingga SMA sederajat. Akan tetapi, bekerja pada sektor industri ini tidak selamanya menempatkan mereka pada bagian pabrik atau produksi saja, bahkan terdapat beberapa dari mereka yang ditempatkan sebagai office boy serta cleaning service.

\section{Hubungan Faktor Internal dengan Persepsi terhadap Pekerjaan Pertanian}

Pada bagian sebelumnya telah dijelaskan bahwa faktor internal pemuda Desa Cihideung Udik yaitu sebagian besar merupakan laki-laki, tidak memiliki keterampilan, tidak memiliki lahan dan memiliki pengalaman bekerja di luar sektor pertanian. Dalam hubungannya dengan persepsi terhadap pekerjaan pertanian, terlihat kecenderungan terhadap persepsi negatif (Tabel 7). 
Tabel 10 Jumlah dan Persentase Responden berdasarkan Topik yang Disukai Ketika Mengakses Internet dan Televisi

\begin{tabular}{lrrlrrr}
\hline \multirow{2}{*}{ Topik } & \multicolumn{2}{c}{ Televisi } & & \multirow{2}{*}{ Topik } & \multicolumn{2}{c}{ Internet } \\
& n & \multicolumn{1}{c}{ \% } & & \multicolumn{1}{c}{$\%$} \\
\hline Acara Musik & 4 & 10,0 & Games online & 4 & 10,0 \\
Drama & 17 & 42,5 & Media sosial & 29 & 72,5 \\
Berita & 2 & 5,0 & Info lowongan kerja & 0 & 0,0 \\
Olah raga & 7 & 17,5 & Ilmu pengetahuan & 4 & 10,0 \\
Musik dan drama & 5 & 12,5 & Games online dan media sosial & 2 & 5,0 \\
Musik dan berita & 2 & 5,0 & Media sosial dan info lowongan keja & 1 & 2,5 \\
Berita dan olahraga & 3 & 7,5 & - & & \\
\hline Jumlah & 40 & 100,0 & Jumlah & 40 & 100,0 \\
\hline
\end{tabular}

Pada tabel 7 dapat diperhatikan bahwa masing-masing variabel memiliki pengaruh berbeda terhadap persepsi terhadap pekerjaan pertanian yang cenderung negatif. Pada variabel jenis kelamin, seluruh responden perempuan memiliki persepsi negatif terhadap pekerjaan pertanian. Rendahnya persepsi seluruh responden perempuan terhadap pekerjaan sektor pertanian disebabkan oleh orientasinya yang kuat terhadap pekerjaan lain. Selain itu juga disebabkan oleh ketidaktahuan responden mengenai kondisi pekerjaan pertanian sesungguhnya saat ini. Berbeda dengan laki-laki yang masih memiliki persepsi positif terhadap pekerjaan pertanian. Hal ini disebabkan oleh responden laki-laki masih ada yang bekerja ke sawah membantu keluarga, serta masih ada yang berasal dari keluarga yang memiliki lahan pertanian yang luas, yang memang sumber mata pencahariannya berasal dari pertanian, dalam artian keluarga petani bukan keluarga buruh tani. Hal ini tampaknya memberi peniliaian yang sedikit berbeda kepada mereka.

Jenis kelamin tidak memiliki hubungan nyata dengan persepsi terhadap pekerjaan pertanian setelah diuji secara statistik, karena saat ini pemuda yang menjadi responden terutama perempuan sudah tidak pernah lagi bekerja ke sawah secara langsung. Mereka tidak tahu bagaimana bertani dan bahkan pendapatan yang dihasilkan oleh pertanian tersebut. Herlina (2002) yang menyatakan bahwa perempuan cenderung mempersepsikan pekerjaan pertanian sebagai pekerjaan yang kurang baik dan kurang pantas untuknya karena pekerjaan pertanian identik dengan bekerja kasar dan berat. Begitupun yang terjadi pada pemuda Desa Cihideung Udik, mereka hanya mengetahui kalau bertani itu melelahkan dan menguras banyak tenaga, selain itu tampilan dari petani yang identik dengan berkeringat dan kotor membuat mereka menjadi terdorong untuk mendapatkan pekerjaan apapun di luar pertanian.

"Gak kenapa-napa sih teh, males aja soalnya kan bertani itu capek teh, panas' ( Sr, 18 tahun).

Pada variabel kepemilikan keterampilan terlihat bahwa pemuda yang tidak memiliki keterampilan apapun cenderung untuk memiliki persepsi yang negatif terhadap pekerjaan sektor pertanian. (Tabel 7) Hasil ini tidak sesuai dengan penelitian Prambudi (2011) yang menyatakan bahwa ketika seorang pemuda tidak memiliki keterampilan untuk bekerja di sektor formal maka ia akan cenderung untuk memiliki persepsi positif terhadap pekerjaan pertanian. Perbedaan hasil yang didapatkan ini dapat disebabkan oleh latar belakang pemuda Desa Cihideung Udik yang selain tidak memiliki keterampilan di sektor lain, juga tidak memiliki keterampilan dalam pertanian. Artinya mereka tidak memiliki keterampilan apapun baik itu di bidang pertanian maupun di luar pertanian. Akan tetapi, ketika responden memiliki keterampilan di luar pertanian, berarti responden telah mempersiapkan diri untuk masuk ke luar sektor pertanian. Keahlian yang dimiliki tersebut tentu tidak akan dibiarkan sia-sia begitu saja, seperti yang dituturkan salah seorang responden.

"Saya pernah les komputer biar bisa mahir komputer teh, jadi nanti bisa kerja di kantorkantor' (Ads, 18 tahun). 
Tabel 11 Jumlah dan Persentase Responden Berdasarkan Waktu yang Dihabiskan Untuk Mengakses Media Massa Dalam Sehari

\begin{tabular}{cccc}
\hline No & Total Waktu & Jumlah responden & Persentase (\%) \\
\hline 1 & $\leq 7$ jam & 26 & 65 \\
2 & $>7$ jam & 14 & 35 \\
\hline Total & 40 & 100 \\
\hline
\end{tabular}

Walaupun demikian tidak terdapat hubungan yang signifikan antara variabel keterampilan dengan variabel persepsi terhadap pekerjaan pertanian setelah dilakukan uji statistik. Hal ini dapat disebabkan oleh keterampilan yang dimiliki kebanyakan diperoleh secara tidak sengaja serta tidak merupakan keterampilan yang mendukung pekerjaan yang diinginkan responden, seperti terdapat keterampilan yang didapat karena orang tua memiliki usaha tersebut atau diajak tetangga untuk mengisi waktu kosong. Contohnya terjadi pada Pbr (18 tahun) yang ayahnyamempunyaiusaha sablon dengan pendapatan yang cukup besar, sehingga setiap hari ia membantu ayahnya dan terampil menyablon karena terbiasa, padahal ia merupakan lulusan SMK perhotelan dan ingin bekerja menjadi polisi. Begitupun dengan yang terjadi pada Yds (18 tahun) yang memiliki keterampilan dalam bangunan karena sering diajak tetangganya untuk membantu bekerja membangun rumah untuk mengisi waktunya sementara belum mendapatkan pekerjaan, sehingga ia pun memiliki keterampilan tersebut, padahal ia merupakan lulusan SMK dengan jurusan administrasi dan ingin bekerja di pabrik. Banyak terjadi kasus seperti itu, pemuda memiliki keterampilan yang tidak sesuai dengan pekerjaan yang diharapkannya.

Pada variabel pengalaman bekerja, adanya pengalaman pekerjaan apalagi di luarsektor pertanian memberi pengaruh sedikit banyaknya pada orientasi dan penilaian pemuda terhadap pekerjaan pertanian. Persespi negatif terhadap pekerjaan sektor pertanian cenderung berada pada pemuda yang telah memiliki pengalaman bekerja sebelumnya (Tabel 7). Mereka telah terkontaminasi dengan kehidupan bekerja di luar pertanian. Pergantian pekerjaan yang mereka lalui membuat mereka dapat belajar bagaimana pekerjaan yang baik dan menyenangkan. Pekerjaan yang menyaratkan pendidikan menjadikan mereka merasa lebih dihargai daripada pekerjaan yang bisa dimasuki oleh siapapun dari berbagai latar belakang pendidikan.

Tabel 7 memperlihatkan persentase persepsi yang negatif terhadap pekerjaan pertanian tidak jauh berbeda antara pemuda yang memiliki pengalaman bekerja sebelumnya (55\%) dengan pemuda yang belum memliki pengalaman bekerja sebelumnya (45\%). Walupun persepsi negatif sebagian besar dimiliki oleh pemuda yang memiliki pengalaman bekerja, namun tidak terdapat hubungan yang signifikan antara kedua variabel tersebut berdasarkan uji statistik korelasi spearman. Hasil olah data SPSS ini menunjukkan bahwa pengalaman bekerja tidak memiliki hubungan dengan persepsi terhadap pekerjaan pertanian, karena nilai $\mathrm{p}(0,457)>$ alpha $10 \%$ sehingga $\mathrm{H} 0$ diterima artinya tidak terdapat hubungan diantara kedua variabel pengalaman bekerja dengan persepsi terhadap pekerjaan pertanian.

Tidak adanya hubungan antara kedua variabel tersebut dapat disebabkan oleh pengalaman bekerja yang dimiliki responden sebagian besar hanya sebentar saja, terdapat beberapa responden yang pernahmemiliki pengalaman bekerja hanya beberapa minggu. Selain itu, pengalaman bekerja yang dimiliki responden ini pada umumnya tidak membahagiakan. Banyak dari pemuda yang melakukan pergantian pekerjaan terkait dengan alasan mereka meninggalkan pekerjaan sebelumnya. Sebagian besar dari mereka meninggalkan pekerjaan sebelumnya karena gaji yang sangat kecil dan jam kerja yang terlalu panjang. Beberapa responden mengaku hanya diberi upah di bawah Rp 750.000,- bahkan ada yang digaji dibawah Rp 500.000,-. Sementara jam kerja mereka sangat panjang yaitu mulai dari pagi sampai malam setiap hari kerja dalam satu minggu.

\section{Faktor Eksternal}

Faktor eksternal yaitu faktor-faktor yang berasal dari luar diri individu yang mempengaruhi persepsi pemuda terhadap pekerjaan sektor pertanian. Dalam hal ini terdapat beberapa faktor yang Tabel 12 Jumlah dan Persentase Responden berdasarkan Tingkat Kosmopolitan

\begin{tabular}{lcc}
\hline $\begin{array}{c}\text { Tingkat } \\
\text { kosmopolitan }\end{array}$ & $\begin{array}{c}\text { Jumlah } \\
\text { (orang) }\end{array}$ & Persentase (\%) \\
\hline Tinggi & 18 & 45 \\
Rendah & 22 & 55 \\
\hline Jumlah & 40 & 100 \\
\hline
\end{tabular}


Tabel 13 Jumlah dan Persentase Responden berdasarkan Jenis Pekerjaan yang Diharapkan Orangtua

\begin{tabular}{lcc}
\hline $\begin{array}{c}\text { Pekerjaan yang } \\
\text { diharapkan }\end{array}$ & $\begin{array}{c}\text { Jumlah } \\
\text { (orang) }\end{array}$ & $\begin{array}{c}\text { Persentase } \\
\text { (\%) }\end{array}$ \\
\hline Dagang & 2 & 5,0 \\
Industri/pabrik & 13 & 32,5 \\
PNS & 4 & 10,0 \\
Ikut kemauan anak & 19 & 47,5 \\
Pertanian & 2 & 5,0 \\
\hline Jumlah & 40 & 100,0 \\
\hline
\end{tabular}

mempengaruhi yaitu status sosial ekonomi keluarga, sosialisasi pekerjaan dan tingkat kosmopolitan.

\section{Status Sosial Ekonomi}

Status sosial ekonomi dalam hal ini dilihat dari kepemilikan lahan, pekerjaan, pendidikan, dan pendapatan kedua orangtua dalam satu bulan, atau dilihat juga dari orang yang menanggung hidup responden selain orang tuanya.

Sebagian besar orangtua responden tidak memiliki lahan pertanian namun pernah memiliki lahan pertanian dalam waktu 10 tahun terakhir. Hal ini disebabkan oleh sebagian besar lahan tersebut dijual untuk kepentingan yang lain. Apalagi di Desa Cihideung Udik saat ini ditemukan beberapa pembangunan perumahan oleh pihak swasta. Lahan yang dulunya pertanian telah banyak dikonversi menjadi perumahan. Selain dijual karena adanya pihak swasta yang membeli, keinginan untuk membuka usaha lain menjadi salah satu penyebab lahan pertanian tersebut dijual. Setelah itu hanya terdapat dua orang reponden yang terdapat masih memiliki lahan diatas $0,5 \mathrm{Ha}$ dan berasal dari orang tua yang bekerja sebagai petani.

Selain petani, orangtua responden terutama untuk ayah, sebagian besar bekerja sebagai buruh. Buruh di sini yaitu terdiri dari buruh lepas, buruh tani, dan buruh pabrik dan setelah itu diikuti oleh pedagang. Banyak dari mereka berdagang keluar dari desa, seperti ke Kota Bogor dan bahkan ada yang sampai ke luar provinsi Jawa Barat yaitu ke Tangerang. Untuk pendapatan orangtua pun memiliki keragaman, yaitu pada rentang $\mathrm{Rp} 1.200 .000$,sampai Rp 5.000.000,- per bulan, dengan rata-rata Rp 2.045.000,- (Tabel 8)

Sebagian besar orang tua responden memiliki pendapatan di bawah rata-rata. Hal ini juga menjadi salah satu pendorong orangtua responden untuk tidak menyekolahkan anak mereka ke jenjang yang lebih tinggi. Mereka lebih cenderung menyuruh dan mangantarkan anak mereka untuk masuk dunia kerja sehingga dapat membantu penghasilan keluarga. Para orang tua responden ini juga memiliki pemikiran bahwa pendidikan yang sudah mencapai tingkat SMA merupakan suatu pencapaian yang tinggi, dan seharusnya anaknya bisa mendapatkan pekerjaan yang layak dan dengan penghasilan yang lebih baik.

Basrowi dan Juariyah (2010) mengatakan bahwa jika semakin tinggi kondisi sosial ekonomi suatu masyarakat maka semakin tinggi pula tingkat pendidikan yang bisa dicapai masyarakat, sebaliknya jika kondisi sosial ekonomi masyarakat rendah maka tingkat pendidikan yang dicapainya juga akan rendah. Melalui kondisi sosial ekonomi yang lebih baik masyarakat akan lebih mudah untuk memberikan kesempatan kepada anaknya untuk bersekolah setinggi yang diinginkan dengan dukungan yang baik. Hasil penelitian tersebut mengindikasikan kondisi sosial ekonomi yang baik akan menciptakan generasi yang berpendidikan lebih baik pula sehingga akan menghasilkan tenaga kerja dengan pendidikan yang lebih tinggi dan lebih produktif.

Seperti yang dapat diperhatikan pada tabel 9, sebagian besar pemuda berasal dari keluarga dengan status sosial ekonomi yang rendah $(62,55)$. Hanya $37,5 \%$ dari mereka yang berasal dari status sosial ekonomi tinggi. Hal ini tentu kurang sesuai dengan pemaparan di atas, karena responden sudah termasuk mereka yang berpendidikan atau terdidik. BPS (2008) mengatakan bahwa jika mereka yang mencari pekerjaan dengan pendidikan minimal SMA termasuk ke dalam golongan terdidik. Dalam kata lain hasil penelitian Basrowi dan Juariyah (2010) kurang sesuai terutama apabila respondennya terfokus hanya kepada mereka yang berpendidikan SMA.

Walaupun pendidikan SMA sudah termasuk terdidik akan tetapi belum sesuai dengan teori tersebut. Hal ini juga tidak sesuai dengan apa yang dikatakan Simanjuntak (1985) yang mengemukakan bahwa tenaga kerja terdidik umumnya datang dari keluarga dengan kehidupan sosial ekonomi yang relative tinggi karena sebagian besar responden berasal dari keluarga dengan status sosial ekonomi 
Tabel 14 Jumlah dan Persentase Persepsi Pekerjaan Pertanian Berdasarkan Faktor Eksternal Responden

\begin{tabular}{|c|c|c|c|c|c|c|c|}
\hline & & \multicolumn{4}{|c|}{ Persepsi pekerjaan pertanian } & \multirow{3}{*}{ Jumlah } & \multirow{3}{*}{ Persentase (\%) } \\
\hline \multicolumn{2}{|c|}{ Faktor eksternal } & \multicolumn{2}{|c|}{ Negatif } & \multicolumn{2}{|c|}{ Positif } & & \\
\hline & & $\mathbf{n}$ & $\%$ & $\mathbf{n}$ & $\%$ & & \\
\hline \multirow{2}{*}{ Status sosial ekonomi } & Rendah & 21 & 64 & 4 & 57,1 & 22 & 62,5 \\
\hline & Tinggi & 12 & 36 & 3 & 42,9 & 18 & 37,5 \\
\hline Jumlah & & 33 & 100 & 7 & 100,0 & 40 & 100,0 \\
\hline \multirow{2}{*}{ Tingkat kosmopolitan } & Rendah & 19 & 58 & 3 & 42,9 & 22 & 55,0 \\
\hline & Tinggi & 14 & 42 & 4 & 57,1 & 18 & 45,0 \\
\hline Jumlah & & 33 & 100 & 7 & 100,0 & 40 & 100,0 \\
\hline \multirow{2}{*}{ Sosialisasi pekerjaan } & Non Pertanian & 24 & 73 & 3 & 42,9 & 27 & 67,5 \\
\hline & Pertanian & 9 & 27 & 4 & 57,1 & 13 & 32,5 \\
\hline Jumlah & & 33 & 100 & 7 & 100,0 & 40 & 100,0 \\
\hline
\end{tabular}

yang tergolong rendah $(62,5 \%)$, akan tetapi mereka bisa mencapai pendidikan hingga ke tingkat SMA yang sudah termasuk golongan terdidik atau berpendidikan.

\section{Tingkat Kosmopolitan}

Kekosmopolitan yaitu keterbukaan seseorang menerima informasi dari luar. Tingkat kosmopolitan di sini dilihat dari keterdedahan responden terhadap media massa dan kontak terhadap kota. Dalam hal keterdedahan dengan media massa ini akan dilihat jumlah media massa yag diakses dan total durasi mengakses media massa tersebut setiap harinya, selain itu juga dilihat topik apa yang disukai dan selalu dikonsumsi oleh pemuda desa. Pada Tabel 10 dapat diperhatikan bahwa pemuda desa saat ini cenderung untuk melihat hiburan saat ia mengakses media massa. Acara musik, drama (sinetron, film dan ftv) dan acara olahraga (pertandingan bola dan badminton) merupakan acara yang paling disukai pemuda saat ini. Begitupun saat mengakses internet. Sebagian besar responden hanya mengkases media sosial $(72,5 \%)$ dan games online.

Terlihat banhwa hanya segelintir saja yang memanfaatkan internet untuk mencari informasi lowongan pekerjaan. Padahal terdapat banyak info lowongan pekerjaan di internet termasuk untuk lulusan SMA sederajat. Mereka mengatakan mencari info lowongan pekerjaan itu adalah hal yang sulit saat ini. Mereka cenderung untuk menerima lowongan pekerjaan dari orang-orang yang mereka kenal, seperti teman, keluarga atau tetangga. Alasannya karena info tersebut lebih jelas dan ada orang yang dikenal di tempat tersebut. Salah seorang responden yang bernama Rdw (19 tahun) mengatakan bahwa:

\section{"sekarang nyari lowongan kerja susah teh, harus ada orang dalam atau didatengin langsung".}

Hal ini sejalan dengan Rohmat (1997) yang menyatakan bahwa pemuda saat ini lebih percaya pada koneksi daripada kompetisi secara terbuka. Sehubungan dengan hal tersebut, waktu yang dihabiskan responden untuk mengakses media massa yang sangat bervariasi, berkisar antara 3 jam hingga 18 jam, namun rata-rata hanya 7 jam dalam sehari ( Tabel 11).

Jumlah responden yang mengakses media massa dibawah 7 jam dalam sehari lebih banyak daripada yang mengakses diatas 7 jam yaitu berjumlah 26 orang atau $65 \%$ dari seluruh total responden. Walaupun demikian, pada jumlah yang hanya $35 \%$ tersebut, terdapat beberapa responden yang mengakses media massa sangat lama baik itu televisi maupun internet. Terdapat enam orang responden yang menghabiskan waktunya lebih dari 12 jam hanya untuk mengakses media massa. Dalam kasus ini, terlihat bahwa ketika pemuda tidak memiliki pekerjaan ataupun suatu pekerjaan yang tetap, mereka cenderung menghabiskan waktunya untuk mengakses media massa.

Adanya kontak dengan kota menggambarkan banyaknya kota yang telah dikunjungi pemuda serta sesering apakah pemuda tersebut pergi ke kota. Dalam kasus pemuda di Desa Cihideung Udik ini, responden paling sedikitnya telah mengunjungi 
Tabel 15 Jumlah dan Persentase Persepsi terhadap Pekerjaan Sektor Pertanian berdasarkan Minat Bekerja Responden

\begin{tabular}{|c|c|c|c|c|c|c|}
\hline \multirow{3}{*}{$\begin{array}{c}\text { Minat } \\
\text { bekerja }\end{array}$} & \multicolumn{4}{|c|}{$\begin{array}{c}\text { Persepsi pekerjaan } \\
\text { pertanian }\end{array}$} & \multirow{3}{*}{ Jmlh } & \multirow{3}{*}{$\begin{array}{r}\text { Persen } \\
(\%)\end{array}$} \\
\hline & \multicolumn{2}{|c|}{ Negatif } & \multicolumn{2}{|c|}{ Positif } & & \\
\hline & jmlh & $\%$ & jmlh & $\%$ & & \\
\hline $\begin{array}{l}\text { Non- } \\
\text { pertanian }\end{array}$ & 26 & 79 & 3 & 43 & 29 & 73 \\
\hline Pertanian & 7 & 21 & 4 & 57 & 11 & 28 \\
\hline Jumlah & 33 & 100 & 7 & 100 & 40 & 100 \\
\hline
\end{tabular}

dua kota yaitu Kota Bogor dan Kota Jakarta dan paling banyak hanya mengunjungi empat kota. Kota yang dikunjungi tersebut hanya berada di sekitar Jabodetabek saja. Ini berarti bahwa pemuda Desa Cihideung Udik tidak terlalu suka meninggalkan desanya untuk bepergian dalam jarak yang cukup jauh. Banyaknya pemuda yang mengunjungi Kota Bogor dan Jakarta ini disebabkan oleh faktor kedekatan dengan desa tempat mereka tinggal serta juga dipengaruhi oleh lancarnya transportasi yang membawa mereka ke daerah tersebut. Kota yang paling sering dikunjungi oleh responden selain Kota Bogor dan Jakarta yaitu Kota Bekasi, Karawang dan Tangerang. Kota yang dikunjungi responden rata-rata merupakan kota yang terdapat industri, pabrik dan perusahaan. Hal ini terkait dengan tujuan responden yang ingin mencari pekerjaan atau melamar pekerjaan ke daerah tersebut. Sebagian besar dari respoden, baru mengunjungi kota selain Kota Bogor ketika ia lulus SMA, dan hal itu dilakukannya karena melamar pekerjaan dan mencari lowongan pekerjaan. Sebagian besar responden hanya pernah mengunjungi dua kota dalam tahun 2013 ini, rata-rata kota tersebut adalah Kota Bogor dan Kota Jakarta yang notabenenya memiliki jarak terdekat dari tempat tinggal mereka. Selain itu, Jakarta memiliki faktor penarik yang kuat karena banyaknya lapangan pekerjaan yang tersedia di ibukota ini. Berdasarkan beberapa faktor yang dijabarkan sebelumnya, secara keseluruhan tingkat kosmopolitan pemuda Desa Cihideung Udik dapat dilihat pada Tabel 12 .

Tabel 12 memperlihatkan tingkat kosmopolitan pemuda Desa Cihideung Udik yang menjadi responden sebagian besar rendah (55\%). Hal ini sebenarnya tidak memiliki perbedaan yang jauh dengan pemuda yang memiliki tingkat kosmopolitan yang tinggi.
Pemuda Desa Cihideung Udik yang memiliki tingkat kosmopolitan tinggi yaitu 18 orang atau $45 \%$ dari total keseluruhan responden.

\section{Sosialisasi pekerjaan}

Pekerjaan yang diperkenalkan kepada anak semenjak kecil serta harapan pekerjaan dari orang tua tentunya akan mempengaruhi keputusan pemuda untuk memilih pekerjaan yang akan ia masuki. Desa Cihideung Udik ini merupakan daerah petanian serta sebagian besar penduduknya masih bekerja di bidang pertanian, untuk itu akan dilihat apakah orangtua masih mensosialisasikan pekerjaan pertanian kepada responden. Berdasarkan data yang didapatkan dari lapangan, orangtua yang masih memperkenalkan pertanian kepada anaknya hanya 30\% dari total seluruh responden. Hal ini dapat diamati seperti pada Gambar 3.

Pada Gambar 3 terlihat bahwa tidak banyak lagi pemuda desa yang diperkenalkan dengan pertanian, baik itu oleh orang tua maupun orang lain yang berada di sekitar responden. Padahal, Desa Cihideung Udik merupakan desa pertanian dan mata pencaharian sebagian besar penduduknya di bidang pertanian. Hal ini disebabkan oleh sebagian pekerjaan orangtua pemuda yang menjadi responden bukan di bidang pertanian, kebanyakan dari mereka hanyalah buruh, baik itu buruh tani, buruh pabrik maupun buruh lepas Responden yang diperkenalkan dengan pertanian hanya 30\%. Hal ini pun hanya sekedar diajarkan dengan mengajaknya dan mengajarkan cara menanam, tidak ada tuntutan pemuda tersebut untuk bisa bertani walaupun orang tua mereka merupakan seorang petani yang memiliki lahan cukup luas dan penghasilan utama keluarga dari bertani. Hal ini seperti yang dialami oleh Sfl (19) yang ayahnya memiliki sawah seluas 1,5 Ha serta

Tabel 16 Jumlah dan Persentase Responden berdasarkan Pilihan Pekerjaan

\begin{tabular}{lcc}
\hline \multicolumn{1}{c}{ Pilihan pekerjaan } & Jumlah & $\begin{array}{c}\text { Persentase } \\
(\%)\end{array}$ \\
\hline Industri/pabrik & 20 & 50,0 \\
Wirausaha & 6 & 15,0 \\
PNS & 3 & 7,5 \\
Bekerja kantoran & 5 & 12,5 \\
Pramuniaga/SPG & 6 & 15,0 \\
\hline Jumlah & 40 & 100,0 \\
\hline
\end{tabular}




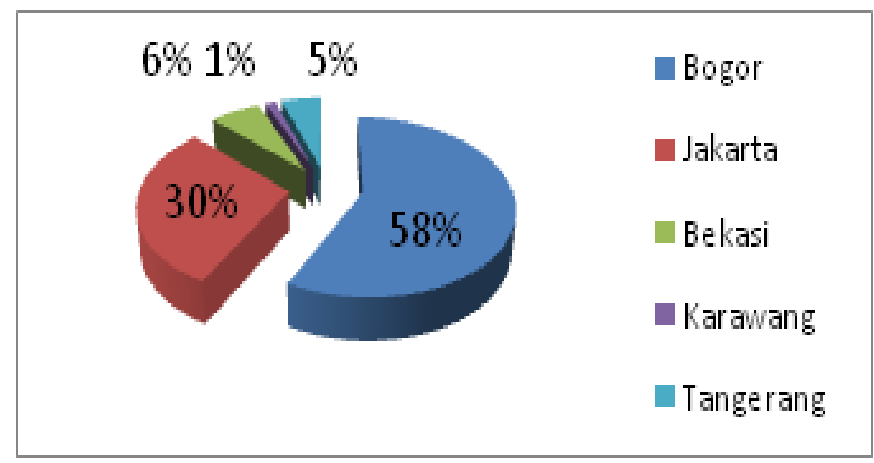

Gambar 4 Daerah pilihan bekerja responden

memiliki kebun, ia sering diajak ke sawah dan kebunnya di waktu kecil tapi ia tidak disuruh untuk bertani. Ia malah di suruh untuk mencari kerja di Jakarta dan sekitarnya.

\section{"Kata ayah mah saya gak usah ke sawah teh, cukup cari kerja aja di Jakarta, sawah mah urusan ayah' ( Sfl, 19 tahun).}

Responden yang berasal dari keluarga petani sekalipun tidak diharapkan untuk melanjutkan pekerjaan pertanian. Gambar 3 memperlihatkan persentase yang sangat kecil untuk harapan orangtua agar anaknya bekerja di pertanian. Hanya 5\% dari seluruh responden yang diharapkan untuk bekerja di sektor pertanian dan ketika dilihat latar belakang keluarga yang mengharapkan anaknya bekerja di sektor pertanian tersebut memiliki kesamaan yaitu dahulunnya pernah menjadi petani yang berhasil. Akan tetapi, saat ini hanya satu orang yang keluarganya masih mengolah pertanian, walaupun tidak menjadi penghasilan utama, tapi masih tetap mengolah pertanian dengan pekerjaan utama menjual sayuran. Bapak Cp (47 tahun) merupakan orang tua dari responden yang masih mengaharapkan anaknya bekerja di sektor pertanian, ia mengatakan bahwa sebenarnya lebih enak menjadi petani daripada pedagang kalau punya lahan yang cukup.

\section{"Sebenarnya lebih enak jadi petani kalau punya lahan mah, sekarang lahan saya sempit, jadi harus dagang ke pasar-pasar tiap har'' (Cp, 47 tahun).}

Pada Gambar 3 terlihat bahwa 95\% dari responden tidak diharapkan untuk bekerja di bidang pertanian. Terkait dengan hal tersebut, walaupun orangtua responden tidak mengharapkan anaknya untuk bekerja di bidang pertanian, akan tetapi mereka juga tidak mengharapkan anaknya bekerja di suatu bidang yang jelas, terdapat beberapa dari orangtua yang menyerahkan pilihan pekerjaan kepada apa yang diinginkan anaknya. Hal ini seperti dapat dilihat secara rinci pada Tabel 13.

Pada saat ditanya harapan pekerjaan untuk anak, sebagian besar atau $47,5 \%$ orang tua tidak mengharapkan pekerjaan apapun pada anaknya. Mereka hanya memberikan kesempatan seluasluas mungkin untuk menentukan pilihan pekerjaan kepada anak mereka sendiri. Akan tetapi, hal yang harus digarisbawahi di sini, sebagian besar orangtua tersebut mengharapkan anaknya tidak bekerja jauhjauh dari desanya. Apalagi untuk perempuan, besar harapan mereka untuk tetap berada di Bogor, dan tidak mengizinkan untuk bekerja di luar Kota Bogor. Hal ini seperti yang diungkapkan Ibu St (34 tahun) salah seorang orangtua responden.

\section{"Kalau ibu mah terserah anak mau nya dimana, asalkan baik aja, dan tetap di Bogor, biar bisa tetap ngumpur' (St, 34 tahun).}

Jika melihat Tabel 13, bekerja di pabrik merupakan harapan pekerjaan yang paling banyak dari orang tua pemuda di Desa Cihideung Udik. Hal ini disebabkan oleh banyaknya pabrik yang membuka lowongan pekerjaan akhir-akhir ini serta pendapatan yang diberikan pabrik tersebut tetap dan berkelanjutan, selain itu persyaratan untuk masuk pabrik yang mudah, hanya dengan membawa ijazah dan surat lamaran, mereka sudah bisa bekerja di pabrik, tanpa mengeluarkan modal apapun lagi. Berbeda dengan bertani atau berdagang yang membutuhkan sejumlah uang untuk modal. Hal ini semakin mendorong orangtua untuk mengharapkan anaknya bekerja di pabrik, agar bisa segera memiliki penghasilan dengan tidak mengeluarkan modal. Tabel 17 Jumlah dan Persentase Responden berdasarkan Harapan Pendapatan

\begin{tabular}{lrr}
\hline Harapan pendapatan (Rp) & $\begin{array}{l}\text { Jumlah } \\
\text { (orang) }\end{array}$ & $\begin{array}{c}\text { Persentase } \\
\text { (\%) }\end{array}$ \\
\hline$<2.000 .000$ & 3 & 7,5 \\
$2.000 .000-3.000 .000$ & 36 & 90,0 \\
$>3.000 .000$ & 1 & 2,5 \\
\hline Jumlah & 40 & 100,0 \\
\hline
\end{tabular}


Selain bekerja di pabrik, dagang dan bertani, masih terdapat 10 persen dari responden yang diharapkan untuk bekerja sebagai pegawai negeri sipil (PNS). Banyak dari orangtua tidak begitu mengharapkan anaknya menjadi PNS karena prosesnya yang terlalu rumit dan memakan waktu yang lama.

\section{Hubungan Faktor Eksternal dengan Persepsi terhadap pekerjaan Pertanian}

Pada bagian sebelumnya telah dijelaskan mengenai faktor eksternal pemuda Desa Cihideung Udik yaitu memiliki status sosial ekonomi rendah, tingkat kosmopolitan rendah dan pekerjaan yang disosialisasikan merupakan pekerjaan di luar sektor pertanian. Hubungan faktor eksternal tersebut dengan persepsi terhadap pekerjaan pertanian dapat dilihat pada Tabel 14.

Suyanto dan Sudarso (2004) mengungkapkan bahwa mereka yang sudah memiliki status sosial ekonomi yang baik akan berusaha mempertahankan kedudukannya dan tidak akan membiarkan anaknya memasuki pekerjaan yang tidak sesuai dengan kondisi mereka. Persepsi terhadap pekerjaan sektor pertanian yang negatif lebih besar berada pada pemuda yang berasal dari status sosial ekonomi keluarga yang rendah yaitu $62,5 \%$. Hal ini disebabkan oleh harapan akan pekerjaan yang lebih baik dari keluarga. Orangtua pemuda mengharapkan anaknya memiliki pendapatan yang jauh lebih baik dari orang tuanya saat ini, dan pekerjaan yang lebih baik tersebut menurut mereka berada pada sektor industri dan sektor lain di luar pertanian. Hal ini disebabkan oleh pertimbangan pendidikan yang telah dimiliki. Salah seorang orang tua responden yang tergolong kepada status sosial ekonomi rendah dan tidak pernah memiliki lahan pertanian.

\section{"Kalau sudah SMA mah ngapain juga bertani lagi neng, sayang ijazah atuh' (Ed, 50 tahun).}

Selain itu, tidak adanya lahan pertanian yang dimiliki oleh keluarga secara tidak langsung akan mempengaruhi pandangan pemuda terhadap pekerjaan pertanian. Petani berlahan akan memiliki pandangan lebih baik terhadap pekerjaan pertanian, sebaliknya mereka yang tidak memiliki lahan biasanya akan menjadi buruh tani dengan bekerja kasar di lahan pertanian orang lain dan memiliki pandangan yang kurang baik terhadap pekerjaan pertanian (Chandra, 2004). Pemuda desa Cihideung Udik yang sebagian besar tidak memiliki lahan pertanian ini hanya melihat pertanian dari buruh tani yang bekerja kasar dengan upah yang kecil sehingga pemuda menilai pekerjaan pertanian itu sebagai pekerjaan yang kurang baik untuk mereka sehingga akan dihindari.

Pada Tabel 14 tidak terlihat adanya hubungan yang cukup signifikan antara status sosial ekonomi keluarga dengan persepsi individu terhadap pekerjaan pertanian. Hal ini didukung oleh hasil olahan data SPSS uji korelasi spearman. Hasil olah data SPSS ini menunjukkan bahwa status sosial ekonomi sama sekali tidak memiliki hubungan dengan persepsi terhadap pekerjaan di sektor pertanian karena nilai $\mathrm{p}(0,903)>$ alpha $10 \%$ sehingga $\mathrm{H} 0$ diterima artinya tidak terdapat hubungan diantara kedua variabel tersebut. Orangtua saat ini baik yang berasal dari status sosial ekonomi rendah maupun tinggi akan selalu memberikan dorongan untuk tidak lagi bekerja di pertanian untuk anaknya. Tidak jauh berbeda dengan Bapak Edi, salah seorang orangtua responden yang merupakan seorang petani dengan luas lahan mencapai 2 Ha mengatakan hal yang sama mengenai harapan pekerjaan untuk anaknya.

\section{"Ya, Kalau bagi Bapak mending cari kerja di Kota sana, gak usah jadi petani kayak Bapak' (Ecp, 57 tahun).}

Berbeda dengan status sosial ekonomi, tingkat kosmopolitan pemuda Desa Cihideung Udik ini memiliki hubungan yang positif dengan persepsi pekerjaan di sektor pertanian. Pemuda yang memiliki persepsi negatif terhadap pekerjaan pertanian cenderung memiliki tingkat kosmopolitan yang rendah. Begitupun sebaliknya, pemuda yang memiliki persepsi yang positif terhadap pekerjaan petanian cenderung memiliki tingkat kosmopolitan yang tinggi yaitu sebesar 57\%. Hasil ini tidak sejalan dengan penelitian Chandra (2004) yang menemukan bahwa semakin tinggi (positif) persepsi pemuda terhadap pekerjaan pertanian semakin rendah tingkat kosmopolitan pemuda tersebut. Perbedaan hasil yang didapatkan ini dapat disebabkan oleh perbedaan latar belakang responden penelitian. Chandra (2004) lebih cenderung meneliti pemuda 
yang masih bekerja di sektor pertanian dengan ratarata pendidikan yang rendah yaitu SD dan SMP. Berbeda dengan penelitian ini yang fokus kepada pemuda pencari kerja dengan pendidikan telah mencapai SMA sederajat yang sebagian besar tidak bekerja di sektor pertanian. Walaupun demikian, tidak terdapat hubungan yang signifikan antara variabel status sosial ekonomi dengan persepsi terhadap pekerjaan pertanian ketika diuji dengan menggunakan uji korelasi Spearman.

Hasil olah data tersebut menunjukkan bahwa tingkat kosmopolitan sama sekali tidak memiliki hubungan dengan persepsi terhadap pekerjaan di sektor pertanian karena nilai $\mathrm{p}(0,477)$ $>$ alpha $10 \%$ sehingga tidak cukup bukti untuk menolak H0 artinya tidak ada hubungan antara variabel tingkat kosmopolitan dengan variabel persepsi terhadap pekerjaan pertanian. Ini dapat disebabkan oleh akses terhadap media massa dan akses ke kota bukan merupakan hal yang tidak asing lagi di Desa Cihideung Udik saat ini. Selain itu pada umumnya pemuda yang mengakses media massa ini hanya mengakses untuk hiburan semata. Pada saat menonton televisi, acara seperti sinetron dan ftv merupakan acara yang paling mereka senangi. Hal ini sedikit banyaknya mempengaruhi cara berfikir mereka dan cara pandang mereka yang lebih berorientasi kepada apa yang mereka lihat tersebut. Suyanto dan Narwoko (2011) menyatakan bahwa media massa mempunyai peranan penting dalam proses transformasi nilai-nilai baru pada masyarakat. Tampaknya hal ini juga terjadi pada pemuda Desa Cihideung Udik yang sebagian besar hanya mengakses hiburan seperti sinetron, ftv dan acara musik ketika menonton televisi sehingga merubah nilai-nilai yang mereka anut menjadi lebih berorientasi kepada apa yang disaksikan setiap hari di sinetron. Kehidupan kota yang terlihat mewah, dan dimanjakan oleh berbagai fasilitas kota yang selalu ditampilkan di sinetron membuat mereka lebih berorientasi pada pekerjaan di kota dan hal ini mempengaruhi pandangan mereka tentang pekerjaan pertanian di desa.

"Kalau di kota itu kan lebih enak teh, tempat kerjanya bagus, fasilitasnya juga lengkap"' (Rmt 18 tahun).

Variabel sosialisasi pekerjaan dibagi atas dua kategori, yaitu sosialisasi pekerjaan pertanian dan sosialisasi pekerjaan di luar sektor pertanian. Hubungan sosialisasi pekerjaan dengan persepsi pemuda terhadap pekerjaan sektor pertanian dapat dilihat pada Tabel 14. Persepsi negatif terhadap pekerjaan pertanian cenderung dimiliki oleh pemuda yang tidak disosialisasikan pekerjaan pertanian. Begitupun sebaliknya, ketika pekerjaan yang disosialisasikan adalah pekerjaan pertanian persepsi pemuda terhadap pekerjaan sektor pertanian cenderung positif (57\%). Hal ini sejalan dengan hasil yang ditemukan Chandra (2004) dalam penelitiannya di Desa Jambudipa yang mengatakan bahwa persepsi terhadap pekerjaan pertanian akan cenderung rendah ketika sosialisasi pekerjaan pertanian juga rendah. Akan tetapi hal ini tidak didukung oleh olah data menggunakan uji Chi-Square. Hasil olah data SPSS ini menunjukkan bahwa variabel sosialisasi pekerjaan dan persepsi terhadap pekerjaan pertanian tidak memiliki hubungan, karena nilai $\mathrm{p}(0,125)$ $>$ alpha $10 \%$ sehingga tidak cukup bukti untuk menolak $\mathrm{H} 0$ artinya tidak ada hubungan antara variabel sosialisasi pekerjaan dengan persepsi terhadap pekerjaan.

Hal ini dapat terjadi karena walaupun masih ada sejumlah orangtua yang mensosialisasikan pekerjaan pertanian kepada anaknya, akan tetapi mereka tidak lagi mengharapkan anaknya untuk bekerja di sektor pertanian tersebut. Para orang tua lebih cenderung untuk mengusahakan anaknya bekerja di sektor non pertanian, terutama banyak yang mengharapkan untuk bekerja di industri/pabrik yang dinilai pekerjaan yang sangat baik untuk anak mereka yang telah mencapai pendidikan hingga tingkat SMA ini.

Walaupun demikian, pada tabulasi silang dapat diperhatikan suatu kecenderungan yaitu responden yang disosialisasikan pekerjaan pertanian akan cenderung untuk memiliki persepsi positif terhadap pekerjaan pertanian dan responden yang tidak disosialisasikan pekerjaan pertanian memiliki persepsi negatif terhadap pekerjaan pertanian. Dapat disimpulkan dari data tersebut bahwa variabel sosialisasi pekerjaan mempengaruhi pembentukan persepsi pemuda desa terhadap pekerjaan pertanian.

\section{Pilihan Pekerjaan Pemuda Desa}

Pemuda Desa Cihideung Udik ini tidak ada 
lagi yang memilih pertanian sebagai pekerjaan utama mereka. Seluruhnya (100\%) memilih pekerjaan di luar pertanian. Mereka lebih memilih pekerjaan lain asalkan tidak pekerjaan pertanian untuk menjadi pekerjaan utama bagi mereka. Walaupun demikian, masih terdapat beberapa pemuda yang mau bekerja di pekerjaan pertanian ini. Akan tetapi tidak untuk menjadi pekerjaan utama, hanya sebagai pengisi waktu luang dan sebagai pekerjaan sampingan untuk menambah penghasilan.

\section{"Saya pengen nyoba bertani teh, nanam sayur di ladang gitu, daripada gak ada pekerjaan yang jelas gini, yah buat ngisi waktu luanglah, sambil nunggu ada lamaran yang diterima, tapi sayangnya saya gak tau caranya bertani teh' (Ads, 21 tahun).}

Kebanyakan dari pemuda desa saat ini tidak tahu lagi bagaimana caranya bertani, hal ini terkait dengan sudah sangat jarang orangtua yang masih mengajarkan pertanian kepada anaknya. Pemuda Desa Cihideung Udik masih mau bekerja di sektor pertanian jika pertanian tersebut menjadi pekerjaan sampingan mereka, tidak menjadi pekerjaan utama karena menurut mereka penghasilan dari pertanian belum cukup untuk memenuhi kebutuhan hidup sehari-hari. Walaupun demikian, mereka masih mau bekerja di pertanian karena menilai bertani memiliki jam kerja yang lebih sedikit, tidak seperti bekerja di restauran atau pekerjaan lain yang pernah mereka alami yang memakan waktu dari pagi hingga malam.

\section{"Gak apa-apalah teh saya mau nyoba bertani, buat nambah penghasilan lumayan teh, lagian kerjaannya gak susah teh, tinggal nanam trus nunggu gak perlu capek-capek kerja dari pagi sampe malem kayak kerja di rumah makan atau toko'(Sfl 19 tahun).}

Lain halnya dengan pemuda yang tidak mau lagi bekerja di sektor pertanian. Sebagian besar dari mereka (59\%) mengemukakan alasan pendidikan yang telah mereka capai, ijazah SMA yang telah mereka dapatkan dengan perjuangan bersekolah selama lebih kurang 12 tahun menjadi alasan utama mereka tidak mau bertani lagi. Mereka menganggap bahwa ijazah mereka akan menjadi sia-sia jika hanya dipergunakan untuk bertani. Hasil ini mendukung pernyataan Tobing (1994) dalam Setiawan (2007) yaitu semakin terdidik seseorang, harapan untuk mendapatkan pekerjaan yang diinginkan juga semakin tinggi. Hal tersebut membuat pemuda terdidik lebih suka memilih menganggur dan menunggu daripada mendapat pekerjaan yang tidak sesuai dengan keinginannya.

Pada bab sebelumnya telah dibahas mengenai persepsi pemuda terhadap pekerjaan di sektor pertanian. Persepsi yang negatif terhadap sektor pertanian akan menyebabkan seseorang lebih memilih pekerjaan diluar sektor pertanian. Begitupun yang terjadi dengan pemuda Desa Cihideung Udik, mereka yang memiliki persepsi yang negatif terhadap pekerjaan sektor pertanian, cenderung untuk memilih pekerjaan di luar sektor pertanian (Tabel 15). Pemuda yang memiliki persepsi yang positif terhadap pekerjaan sektor pertanian, cenderung untuk masih mau bekerja di bidang pertanian.

Pada Tabel 15 terlihat 57\% responden yang masih mau bekerja di sektor pertanian dengan persepsi positif. Pemuda yang berminat bekerja di sektor pertanian ini mengatakan tidak berarti mereka mau terjun seutuhnya di bidang pertanian. Mereka mau bekerja di pertanian jika pertanian ini tidak menjadi pekerjaan utama mereka. Dalam arti kata, mereka menjadikan pertanian hanya sebagai pekerjaan sampingan saja. Pemuda yang mengatakan tidak berminat lagi bekerja di sektor pertanian mengambil persentase yang sangat besar yaitu $73 \%$ secara keseluruhan. Walaupun demikian, sebenarnya responden yang memiliki minat bekerja di non pertanian ini masih mau bekerja di pertanian jika mereka memiliki keterampilan dalam bertani tersebut dan diberi lahan serta modal. Ketidaktahuan dalam cara bercocok tanam yang baik serta tidak adanya lahan yang cukup untuk bertani melemahkan minat mereka terhadap pertanian. Selain itu, bekerja secara berkelompok dalam bertani menjadi salah satu harapan pemuda desa jika tetap harus bekerja di pertanian sehingga pekerjaan pertanian yang sangat melelahkan menurut mereka tersebut dapat sedikit menjadi lebih ringan.

\section{Pilihan pekerjaan non pertanian}

Berdasarkan datayang didapatkan dari pemuda Desa Cihideung Udik yang menjadi responden untuk penelitian ini, pekerjaan yang menjadi pilihan saat ini 
yaitu bekerja di industri/pabrik, berwirausaha, PNS, bekerja kantoran dan menjadi pramuniaga/SPG ( Tabel 16).

Pekerjaan yang paling banyak menjadi pilihan responden yaitu bekerja di industri atau pabrik. Hal ini disebabkan oleh banyaknya pembukaan lowongan pekerjaan dari pabrik/industri saat ini. Selain itu, informasi mengenai adanya lowongan pekerjaan di sektor ini sangat mudah didapatkan oleh responden melalui orang-orang yang berada di sekitarnya. Kepastian gaji yang akan didapatkan setiap bulannya serta kemudahan dalam proses memasuki sektor tersebut menjadi faktor yang membuat pemuda berlomba-lomba untuk mendapatkan pekerjaan di industri/pabrik ini. Hal ini sejalan dengan penelitian Rinihastuti (2010) tentang penilaian pemuda terhadap sektor industri, ia menemukan bahwa alasan rasional pemuda desa memilih pekerjaan di sektor industri adalah alasan ekonomi dan upah, alasan tingkat pendidikan, alasan keinginan belajar mandiri, alasan yang bersifat sosial seperti prestise dan jaringan sosial yang berhubungan dengan relasi pertemanan, terakhir yaitu alasan gaya hidup dan pergaulan pada kaum industri yang lebih modern.

Selain sektor industri, khususnya untuk perempuan yang dipilih menjadi responden dalam penelitian ini, banyak yang lebih memilih pekerjaan sebagai SPG (Sales Promotion Gir). Mereka menilai pekerjaan ini lebih menarik dari pekerjaan apapun karena selain tempat kerja yang enak dan gaji yang pasti, mereka bisa tampil cantik selama bekerja. Lowongan untuk menjadi SPG ini dinilai banyak terbuka saat ini dan salah satu persyaratan untuk bisa melamar pekerjaan menjadi SPG ini adalah lulusan SMA sederajat. Adanya persyaratan pendidikan membuat pekerjaan ini menjadi lebih bernilai dan lebih berarti di mata para pemudi di Desa Cihideung Udik. Salah seorang responden menyatakan hal tersebut ketika ditanya alasan memilih pekerjaan SPG.

\section{"Jadi SPG itu gak semua orang bisa masuk teh, hanya yang berpendidikan SMA aja, kerjaannya juga enak, cantik lagi kalau diliat' ( $\mathrm{Sr}, 18$ tahun).}

Pilihan pekerjaan yang memiliki persentase sama dengan SPG tersebut yaitu menjadi wirausaha. Berwirausaha diartikan sebagai membuka usaha sendiri. Usaha yang ingin dibuka oleh responden ini bermacam-macam seperti ingin membuka toko baju berupa distro, membuka bengkel sendiri, membuka usaha service handphone danusaha sablon. Persentase pilihan pekerjaan setelah wirausaha yaitu bekerja di kantoran. Hal ini dipengaruhi oleh pendidikan yang dimiliki oleh responden yang merupakan lulusan SMK dengan jurusan perkantoran. Bekerja di kantor bagi responden merupakan pekerjaan apa saja yang mengurusi administrasi suatu perusahaan atau instansi dan bekerja dalam ruangan. Dalam artian tidak mengeluarkan banyak tenaga dan tempat bekerja yang enak.

\section{Daerah pilihan bekerja}

Daerah pilihan bekerja ini dilihat dari kota yang paling banyak diajukan lamaran pekerjaan oleh responden. Berdasarkan data yang diperoleh dari pemuda Desa Cihideung Udik yang menjadi responden, daerah tempat mengajukan surat lamaran pekerjaan yaitu sekitar Bogor, Jakarta, Bekasi, Karawang, dan Tengerang (Gambar 4).

Kota Bogor menjadi daerah destinasi mencari pekerjaan utama bagi responden. Faktor yang menjadi alasan utama responden yaitu karena tidak terlalu jauh dengan desa mereka, sehingga mereka masih bisa tinggal dan berkumpul bersama keluarga. Tidak hanya responden, orang tua dari responden pun berpendapat yang sama, apalagi jika anaknya perempuan, mereka berharap untuk tidak bekerja jauh-jauh dari rumah. Hal ini seperti yang diungkapkan Ibu St (34 tahun) salah seorang orangtua responden.

\section{"Kalau ibu mah terserah anak mau nya dimana, asalkan baik aja, dan tetap di Bogor; biar bisa tetap ngumpur' (St, 34 tahun)}

Daerah kedua yang menjadi pilihan responden untuk bekerja yaitu Kota Jakarta. Ibukota negara ini memang selalu menjadi pilihan untuk mencari pekerjaan bagi migran yang berasal dari berbagai daerah di Indonesia. Kota Jakarta dinilai memiliki banyak lowongan pekerjaan yang selalu terbuka setiap saat. Selain itu transportasi yang lancar, fasilitas yang banyak ditawarkan kota Jakarta menjadi faktor penarik yang besar bagi pemuda untuk mencari pekerjaan di daerah tersebut. Selain kedua kota di atas, terdapat Kota Bekasi, Karawang,dan Tangerang yang 
menjadi tujuan bekerja responden. Hal ini disebabkan oleh kota tersebut merupakan kota industri. Banyak industri besar yang memproduksi barang-barang kebutuhan hidup sehari-hari di daerah tersebut. Ini memiliki kaitan yang sangat erat dengan pilihan pekerjaan pemuda yang telah dibahas sebelumnya, yang memperlihatkan sebagian besar pemuda lebih memilih pekerjaan di industri/pabrik.

Alasan utama yang menyebabkan banyaknya responden memilih daerah Bogor sebagai pilihan untuk bekerja yaitu jaraknya yang dekat dengan rumah mereka. Hal ini ditemukan juga pada saat responden ditanyai minat bekerja di luar negeri. Hampir seluruh responden yaitu 95\% responden menyatakan tidak mau bekerja di luar negeri sebagai TKI (Tenaga Kerja Indonesia). Padahal menurut cerita Bapak Misnan, sekretaris Desa Cihideung Udik, terdapat sekitar 6 orang warga Desa Cihideung Udik yang menjadi TKI ke negara Arab dan Malaysia, dan hampir semuanya sukses di sana. Hal ini tidak hanya diketahui oleh sekretaris desa saja, tapi sebagian besar warga mengetahui hal tersebut termasuk pemuda. Walaupun demikian, pemuda Desa Cihideung Udiki tetap tidak mau bekerja menjadi TKI dengan alasan utama jauh.

\section{Harapan pendapatan}

Salah satu tujuan utama seseorang bekerja yaitu untuk mendapatkan imbalan berupa upah atau pendapatan. Sumarsono (2003) mengatakan upah yaitu sesuatu penerimaan sebagai imbalan dari pengusaha/lembaga kepada karyawan untuk suatu pekerjaan atau jasa yang telah dilakukan yang diberikan dalam bentuk uang atas dasar kesepakatan. Harapan pendapatan yaitu upah yang diharapkan oleh seseorang sebagai imbalan atas pekerjaan atau jasa yang telah ia lakukan dalam satuan waktu tertentu. Harapan pendapatan yang dilihat pada pemuda Desa Cihideung Udik ini yaitu harapan pendapatan yang akan diterimanya dalam sebulan ketika medapatkan pekerjaan.

Pemuda Desa Cihideung Udik mengharapkan pendapatan yang dapat memenuhi kebutuhan hidup mereka dan sesuai dengan standar. Seperti ungkapan salah seorang responden, Ads (21 tahun) yang sebelumnya telah memiliki pengalaman bekerja, "Saya juga nggak berharap tinggi-tinggi amat sih teh,yang penting bisa memenuhi kebutuhan saya, ya kalau bisa lebih sih, sesuai standar lah'. Hal yang sama juga dikemukakan salah seorang responden yang belum pernah memiliki pengalaman bekerja sebelumnya, "Saya cuma mau sesuai standar atau UMR aja teh, saya juga nyadar cuma lulusan SMK" (Dd ,19 tahun).Harapan pendapatan responden secara rinci dapat dilihat pada Tabel 17.

Tabel 17 memperlihatkan hampir seluruh responden yaitu $90 \%$ dari total keseluruhan responden memiliki harapan pendapatan pada rentang Rp 2.000.000- Rp 3.000.000,-. Khususnya mereka berharap mendapatkan upah Rp 2.000.000,- sesuai dengan UMR Kota dan Kabupaten Bogor. Bahkan, ada $7,5 \%$ dari responden mengharapkan pendapatan di bawah UMR.

\section{Kesimpulan}

Persepsi para pemuda pencari kerja terhadap pekerjaan pertanian di Desa Cihideung Udik secara keseluruhan adalah negatif. Hal ini disebabkan oleh pemuda yang menjadi responden merupakan pemuda yang sedang mencari pekerjaan dengan pendidikan SMA sederajat. Selain itu juga disebabkan oleh latar belakang keluarga pemuda yang tidak lagi berasal dari keluarga petani dan tidak memiliki lahan pertanian.

Pemuda Desa Cihideung Udik lebih memilih bekerja di luar sektor pertanian yaitu sektor industri atau pabrik. Daerah pilihan bekerja pemuda tersebut sebagian besar di daerah Bogor dengan alasan dekat dengan rumah dan keluarga. Dalam memilih pekerjaan pemuda di sini memiliki harapan pendapatan yang mereka terima sesuai dengan standar UMR daerah setempat.

Tidak terdapat hubungan yang signifikan pada variabel internal maupun eksternal ini ketika dilakukan uji statistik. Akan tetapi dapat dilihat beberapa informasi dari variabel tersebut. Seluruh responden perempuan memiliki persepsi negatif terhadap pekerjaan pertanian.Pemuda akan memiliki persepsi negatif pada pekerjaan pertanian ketika tidak memiliki keterampilan atau keahlian di luar sektor pertanian. Begitupun dengan pemuda yang memiliki pengalaman bekerja di luar sektor pertanian cenderung untuk memiliki persepsi yang negatif terhadap pekerjaan sektor pertanian. Status sosial ekonomi rendah cenderung berpresepsi negatif terhadap pekerjaan pertanian. Semakin rendah tingkat kosmopolitan semakin negatif persepsi terhadap 
pekerjaan sektor pertanian. Sosialisasi pekerjaan non pertanian cenderung membuat persepsi pemuda terhadap pekerjaan pertanian negatif.

\section{Daftar Pustaka}

Anshori MYA. 2011. Persepsi generasi muda pedesaan untuk bekerja di sektor pertanian dan faktor-faktor yang mempengaruhinya (Studi di desa Slamet, Kecamatan Tumpang, Kabupaten Malang).[skripsi]. Malang (ID): Universitas Brawijaya

[BPS]. Badan Pusat Statistik. 2013. Istilah statistik . [internet]. [dikutip 5 Mei 2013]. Tersedia dari: http://bps.go.id/

Basrowi, Juariyah S. 2010. Analisis kondisi sosial ekonomi dan tingkat pendidikan masyarakat Desa Srigading, Kecamatan Labuhan Maringai, Kabupaten Lampung Timur. Jurnal Ekonomi dan pendidikan. [internet].[dikutip 5 Mei 2013]. Tersedia dari: http://journal.uny.ac.id/index.

Chandra D. 2004. Persepsi pemuda desa terhadap pekerjaan di sektor pertanian dan minat kerja di kota. [skripsi]. Bogor (ID): IPB

Cartmel F, Furtlog A. 2000. Youth employment in rural areas. [internet]. [dikutip 25 Maret 2013]. 56 hal. Tersedia dari: http://www.jrf.org.uk/ sites/files/jrf/1859353126.pdf

[Depnakertrans] Departemen tenaga kerja dan transmigrasi. 2012. Penduduk yang bekerja menurut golongan umur dan lapangan usaha. [internet]. [dikuti tanggal 4 Oktober 2013]. Tersedia dari: pusdatinaker.balitfo. depnakertrans.go.id

Friedman HS, Schutack MW. 2006. Kepribadian, teori klasik dan riset modern.Widyasinta B, penerjemah. Hardani W, editor. Jakarta (ID): Erlangga. Terjemahan dari: Personality, classic theories and modern research. Ed ke-3.

Herlina. 2002. Orientasi nilai kerja pemuda pada keluarga petani perkebunan. [tesis].[internet]. [Dikutip tanggal 4 Oktober 2013]. Tersedia dari: http://repository.ipb.ac.id.

Ina M. 2012. Persepsi. [internet]. Dapat diunduh dari: http://eprints.uny.ac.id

Leavitt HJ. 1978. Psikologi Manajemen. Jakarta (ID): Erlangga

Khairani M. 2013. Psikologi umum. Jogjakarta ID): Aswaja presindo.
[Kemenpora] Kementrian Negara Pemuda dan Olahraga. 2008. Penyajian data dan informasi kementrian nasional pemuda dan olahraga. Jakarta (ID): Kementrian nasional pemuda dan olahraga. 163 hal.

[Kementan] Kementrian Pertanian. 2012. Perencanaan tenaga Kerja Sektor Pertanian tahun 2012-2014. [internet]. [Dikutip 1 Januari 2014]. Tersedia dari: http://www.deptan.go.id/ pug/admin/file/GABUNGAN.pdf

Malau A. 2011. Jumlah Angkatan Kerja di Sektor Industri naik Agustus 2011. [internet]. Dikutip tanggal 6 Oktober 2013. Tersedia dari: http:// www.tribunnews.com

Murtiyanti. 2005. Karakteristik peternak domba/ kambing dengan pemeliharaan digembala/ angon dan hubungannya dengan tingkat adopsi inovasi teknologi. Seminar Nasional Teknologi Peternakan dan Veteriner 2005.[internet]. [diunduh tanggal 25 November 2013]

Parlina FK. 2012. Hubungan Tingkat Kosmopolitan dengan Tingkat Adopsi Terhadap Sistem Pertanian Terpadu (Sistem Integrasi PadiTernak) Di Kabupaten Serdang Bedagai (Studi kasus : Desa Lubuk Bayas Kecamatan Perbaungan).[skripsi].[internet].[dikutip tanggal Agustus 2013]. Dapat diunduh dari: http://repository.usu.ac.id

Prabowo H. 2012. Faktor yang mempengaruhi keputusan tenaga kerja desa untuk bekerja di luar sektor pertanian. [skripsi]. [internet]. [dikutip tanggal 27 Desember 2013]. Dapat diunduh dari: http://eprints.undip.ac.id

Pemuda Langka Bekerja di Sektor Pertanian. 2011 September. Pikiran rakyat Online. [internet]. [Dikutip tanggal 5 Oktober 2013]. Tersedia dari: http://www.pikiran-rakyat.com

Puspasari S. 2010. Persepsi dan partisipasi peladang berpindah dalam kegiatan pengembangan tanaman kehidupan model HTI terpadu di Kalimantan Barat. [skripsi]. [internet]. Dapat diunduh dari: http://repository.ipb.ac.id

Prasodjo NW, Pandjaitan NK. 2003. Stratifikasi sosial. Dalam : Sosiologi umum. Tim Editor Sosiologi Umum, editor. Bogor [ID]. Pustaka Wirausaha Muda Bogor. 114 hal.

Prihatmoko H.2013. Jumlah pekerja di sektor pertanian terus menurun. [internet]. [Dikutip tanggal 6 Oktober 2013]. Dapat diunduh dari 
:http://www.bisnis.com

Raharjo. 2004. Pengantar sosiologi pedesaan dan pertanian.. Jogjakarta (ID): Gajah Mada University pres. 238 hal.

Rakhmat J. 2003. Psikologi komunikasi. Bandung (ID): PT Remaja Rosdakarya

Rinihastuti D. 2010. Pemilihan pekerjaan di sektor industri kecil dan rumah tangga (Studi kasus pada Pemuda di Desa Sidoleren, Kecamatan Gebang, Kabupaten Purworejo). [skripsi]. [internet]. [diunduh tanggal 25 November 2013]. Tersedia dari: http://dglib.uns.ac.id

Rohmad Z. 1997. Peran pemuda dalam pembangunan masyarakat pedesaan. [tesis]. [internet]. Tersedia dari: :http://repository.ipb.ac.id

Rusli S. 2012. Pengantar ilmu kependudukan. Jakarta (ID): LP3ES. 239 hal.

Setiawan SA. 2007.Pengaruh umur, pendidikan, pendapatan, pengalaman kerja,dan jenis kelamin terhadap lama mencari kerja bagi tenaga kerja terdidik di kota. [skripsi].[internet].[dikutip 5 Mei 2013]. Dapat diunduh dari: http://eprints. undip.ac.id

Simanjuntak PJ. 1985. Pengantar ekonomi sumber daya manusia. Depok (ID): Lembaga Penerbit Fakultas Ekonomi UI. 136 hal.

Singarimbun M.1989.Metode penelitian survai. Singarimbun M, Effendi S, editor. Jakarta (ID): LP3S.

Sumarsono S. 2003. Ekonomi manajemen sumber daya manusia dan ketenagakerjaan. Jogjakarta (ID): Graha Ilmu. 304 hal.

Suyanto B, Sudarso. 2004. Sosiologi, teks pengantar dan terapan. Narwoko JD, Suyanto B, editor. Jakarta [ID] Kencana Prenada Media Group. 455 hal.

Thoha, M. 2007. Perilaku organisasi konsep dasar dan aplikasinya. Jakarta (ID): PT. Raja Grafindo Persada

Triputrajaya AI. 2011. Preferensi pekerja dalam memilih pekerjaan sektor formal. ILTEK [internet].November 2013 [diunduh tanggal 25 November 2013]. 6 (12).

Yulianto. 1997. Faktor yang mempengaruhi perilaku bekerja pemuda anak tani di pedesaan. [skripsi]. Bogor (ID): IPB

Yunita. 2011. Strategi peningkatan kapasitas petani padi sawah lebak menuju ketahanan pangan rumah tangga di kabupaten Ogan Ilir dan Ogan komering Ilir provinsi Sumatera Selatan. [tesis]. Bogor (ID): IPB. 